\title{
Discursos, pedagogías y estereotipos en la natación femenina argentina a principios del siglo XX
}

\author{
Representations of female swimming towards the first decades of the 20th century in the Argentine press sports \\ practices-history-female gender-bodies- stereotypes
}

\section{Gisela Kaczan}

CONICET. Facultad de Arquitectura Urbanismo y

Diseño. Universidad Nacional de Mar del Plata, Argentina

gisela.kaczan@gmail.com

(iD https://orcid.org/0000-0003-1511-4724

Agustina González

Facultad de Arquitectura Urbanismo y Diseño.

Universidad Nacional de Mar del Plata, Argentina

gonzalezgilardi@gmail.com

(iD https://orcid.org/0000-0002-4715-0765

\section{Resumen:}

Este trabajo busca rastrear cómo se fue introduciendo la práctica deportiva de la natación en centros urbanos como Buenos Aires, en Argentina, especialmente en el género femenino y en perspectiva histórica. Para ello se analizarán diferentes representaciones que circularon en las primeras décadas del siglo XX, con el fin de detectar los discursos a favor y en contra de su ejercicio, las pedagogías, los escenarios y móviles, así como los estereotipos predominantes.

El significado del cuerpo tiene un lugar central en este estudio, atravesado por el paradigma del binarismo sexual, fuertemente ligado a la necesidad de establecer claros roles para uno u otro género, por lo que se recurre al marco de las críticas feministas y la mirada interseccional.

Para ahondar en los objetivos, se trabajará en la interpretación de diferentes productos editoriales de los medios masivos de comunicación, dado que ellos se encargaron de construir y difundir los estereotipos que legitimaban.

Palabras Clave: Prácticas deportivas, Historia, Género femenino, Cuerpos, Estereotipos.

\section{Abstract:}

This work seeks to trace how the sports practice of swimming was introduced in urban centers such as Buenos Aires, in Argentina, especially in the female gender and from a historical perspective. For this, different representations that circulated in the first decades of the 20th century will be analyzed, in order to detect the discourses in favor and against their exercise, the pedagogies, the scenarios and mobiles, as well as the predominant stereotypes.

The meaning of the body has a central place in this study, traversed by the paradigm of sexual binarism, strongly linked to the need to establish clear roles for one gender or another, which is why the framework of feminist criticism and the intersectional view is used.

To delve into the objectives, we will work on the interpretation of different editorial products of the mass media, since they were in charge of building and disseminating the stereotypes that they legitimized.

KEYWORDS: Sports practices, History, Female gender, Bodies, Stereotypes.

\section{A) INTRoducción}

Este trabajo busca rastrear cómo se fue introduciendo la práctica deportiva de la natación en centros urbanos como Buenos Aires, en Argentina, especialmente en el género femenino. ${ }^{1}$ Para ello se analizarán 
diferentes representaciones que circularon en las primeras décadas del siglo XX dado que es el tiempo en el cual la práctica se incorpora y se integra con mayor aceptación, vinculadas con los discursos a favor y en contra de su ejercicio, con las pedagogías, los escenarios y móviles, así como con los estereotipos predominantes. El objetivo no es examinar en la natación en sí misma, aunque esto haya habilitado la construcción de un corpus teórico para poner en diálogo las variables sino, reconocer que se trata de una práctica social en la que confluyeron -no siempre en simultáneo- argumentos higiénicos, eugenésicos, estéticos, distintivos y competitivos que permiten la lectura de diferentes marcas de género. Se cree necesaria la incorporación de la mirada crítica de los estudios feministas para poner en cuestión la naturalidad con la que ciertos hechos fueron observados y vividos.

El recorrido se hace por diferentes productos editoriales de los medios masivos de comunicación dada su trascendencia social y cultural, en tanto allí se publicaron algunos de los principales referentes de la vida moderna de los argentinos. Hemos estudiado el contenido informativo escrito en notas de diferente índole y el contenido visual en imágenes analógicas -grabados, ilustraciones y fotografías, sin detenernos en la dimensión estética, sino en aquello que la trasciende, el significado.

Es así que en primer lugar se hablará sobre las relaciones entre deporte y cuerpo, en segundo lugar se expondrán los aspectos metodológicos enfocados desde las teorías feministas, en tercer lugar y subdividido en apartados se interpretará el corpus historiográfico seleccionado referente a las pedagogías iniciales, las experiencias de sociabilidad, la construcción de estereotipos genéricos y la práctica competitiva, para arribar, finalmente, a algunas reflexiones.

Los estudios sobre el deporte y las prácticas físicas en Argentina vinieron, inicialmente, del campo del periodismo, hasta que comenzaron a abrirse líneas de investigación en historia social sobre el cuerpo y la educación física, para sumarse diálogos interdisciplinares relacionados con ámbitos del Estado y las políticas públicas. $^{2}$ En este marco se inscribe el desarrollo de la natación, largamente ignorada, dada la escasez de estudios en relación con el interés que han despertado otros deportes, como el fútbol o las gimnasias. ${ }^{3}$ Este enfoque no cuenta con una extensa bibliografía en el contexto nacional en perspectiva histórica, ${ }^{4}$ especialmente el estudio de la natación femenina es novedoso y tiene un alto potencial para transparentar algunos de los imaginarios que giraron en torno a la condición femenina y las prácticas físicas, para descifrar de una forma no convencional las marcas y escisiones entre las formas de autonomía corporal y las imposiciones sociales, para indagar en la circulación de estereotipos de género fuertemente asentados en las modalidades de dominación masculina y la matriz heteronormativa.

\section{B) Algunas relaciones entre deporte y Cuerpo}

El deporte ha sido una temática poco atractiva para el saber científico hasta no hace tanto tiempo, cuando con la apertura de las ciencias sociales a partir del llamado giro cultural, comenzó a ser posible estudiar a los actores, sus subjetividades y la dimensión simbólica de sus prácticas. En este sentido, las primeras incursiones de Elías y Dunning (1992) y Gutmann (1978) pusieron de relieve la especificidad del deporte y la importancia de su estudio en el contexto donde se desarrollaba. Los aportes como los de Bourdieu (1991), Vigarello (1982, 2005, 2007), Chartier (1982) entre otros, reconocieron que las prácticas deportivas constituyen espacios sociales relacionales y conectados con las demás áreas de la vida social.

Es un fenómeno cultural complejo en el que la experiencia corporal resulta una condición indefectible. Se pone en juego el cuerpo y se objetivan diferentes dimensiones y representaciones de su contexto, las de disciplinamiento y control, las políticas y patrióticas, las científicas e higiénicas, las lúdicas, las estéticas, las diferencias entre los sexos, entre otras. De acuerdo con esto, Vigarello $(1982,2005,2006)$ señala que el deporte se enfoca hacia un control del cuerpo según unas modalidades que tienden a sustituir la disciplina visible de la gimnasia por coacciones abstractas y colectivamente interiorizadas de las reglas a respetar, de 
las tácticas a seguir, de los records a superar. Nació en una etapa en la cual se miró al cuerpo desde el punto de vista de su eficiencia mecánica, proveniente de una nueva percepción del trabajo, análoga a la del gesto industrial racionalizado de la época. Se basó en la necesidad de una apreciación cuantitativa del esfuerzo muscular, el cuerpo estaba totalmente tecnificado, se desplegaron principios relacionados con propiciar vigor y los desplazamientos fueron fragmentados. Se acrecentaron los preceptos pedagógicos en las instituciones educativas apuntando a la uniformidad de las posturas. La educación física no solo mejoraba los cuerpos, sino que a través del proceso de entrenamiento, se modificaba la vida y se actuaba sobre el organismo en su totalidad (Vigarello, 2005). Así, el cuerpo fue concebido como la puerta de entrada al mejoramiento de la especie humana en su conjunto.

Estos cuerpos tienen características inexorables, se trata de cuerpos sexuados y genéricos, dos conceptos que se activan mutuamente. Según apunta Tubert el género no puede entenderse sin el sexo y viceversa, dado que la categorización social de la biología influye en la construcción social del género así como las categorías sociales de género influyen en la construcción de las categorías biológicas (Tubert, 2003). Estas categorías asimétricas entre mujeres y varones deben concebirse en relación con otros campos de sentido porque están sujetas a las relaciones de poder que organizan y justifican el conjunto de interconexiones en las experiencias sociales, que le dan morfología, le imponen límites y construcciones imaginarias. Así, los atributos de género, las actuaciones, los gestos, los deseos y los modos con los cuales un cuerpo se visibiliza, no serían expresivos sino performativos (Butler, 1988).

Estas nociones calaron hondo en las representaciones de las prácticas de la cultura física y entre ellas en la natación. En los inicios del siglo XX los ejercicios corporales, su enseñanza y difusión están atravesados por el paradigma del binarismo sexual, fuertemente ligado a la necesidad de establecer claros roles para mujeres y para varones. Según el modelo historiográfico que caracterizaba los estereotipos de lo masculino y de lo femenino consolidados en el pensamiento moderno, los varones eran racionales, activos y tenían el mundo público como escenario de acción, mientras que las mujeres eran emocionales, pasivas y encontraban en la esfera doméstica su lugar de pertenencia. Esto se transparentó en el diagrama de lenguajes corporales y gestuales así como en un repertorio kinético que identificó lo femenino a partir de la diferencia con lo masculino.

\section{c) Aspectos metodológicos}

Para abordar los objetivos se recurrió al marco crítico de los estudios feministas. La incorporación de estos enfoques al análisis histórico amplió los temas de investigación de la disciplina e innovó las metodologías de trabajo. Así desde las primeras feministas hacia el siglo XIX los aportes -ni lineales ni superadores unos de otros- pusieron en discusión temas como el derecho a la igualdad entre mujeres y varones, el determinismo biológico, la desencialización de las categorías prevalentes, la resignificación del término "mujer" y "género", la necesidad de un pensamiento interseccional, entre otros tantos.

Actualmente uno de los referentes a partir de los cuales se interpreta la noción de género es J. Scott (1999, [1986]). Para ella, es el elemento constitutivo de las relaciones sociales basadas en las diferencias que distinguen los sexos y como una forma primaria de relaciones significantes de poder. Por su parte, J. Butler repiensa la noción de género y en su propuesta desestabiliza conceptos como mujer y varón para mostrar de qué manera la realidad socio-cultural los sujeta discursivamente, produciendo sus cuerpos en y dentro de las categorías de sexo binario, originario y naturalizado, así la heterosexualidad "una rejilla de inteligibilidad cultural a través de la cual se naturalizan cuerpos, géneros y deseos” (2007, p. 292). Siguiendo a Butler (2007) un cuerpo no es una condición estática, sino que es resultante de un proceso donde las normas reguladoras materializan el "sexo" a partir de la reiteración forzada de esas normas.

Los aportes de las críticas feministas demostraron tener en algunos aspectos una limitante, estaban sesgados por la clase de mujeres, eran blancas, burguesas, heterosexuales que silencian otros tipos de experiencias. 
Allí empezaron a escucharse las voces de las feministas negras para integrar una mirada interseccional. El concepto fue propuesto por K. Crenshaw (1989) con el fin de demostrar cómo hay un sistema de estructuras de opresión, múltiples y simultáneas, en las que la raza y el género interactúan en las formas de discriminación de las mujeres negras. La propuesta es amplia y no acabada aún por las autoras que la emplean ${ }^{5}$ y es muy valiosa porque permite visibilizar los efectos simultáneos de discriminación que pueden generarse en diferentes contextos porque la opresión tiene varios vectores, como la raza, la clase, la corporalidad, el género, entre muchos. A través de ella se pueden interpretar de otra forma los sistemas de opresión ya que aporta nuevos matices y variantes para repensar estrategias de dominación y dimensiones de desigualdad. Los sistemas de dominación se dan interseccionalmente.

Desde aquí y desde una concepción de la investigación cualitativa, abordaremos nuestra propuesta a partir de los discursos e imágenes que circularon en ciertos medios de comunicación, dado que son instrumentos a través de los cuales se puede acceder a la cosmovisión de un determinado contexto histórico, ligados de diversas maneras a ciertos grupos hegemónicos de poder. Se puede pensar que la prensa articularía una matriz de dominación múltiple que instala lógicas patriarcales, heteronormativas, racistas y clasistas que se co-constituyen dinámicamente (Cubillos, 2014).

Se ha consultado un variado repertorio de revistas nacionales y fuentes internacionales, algunas de interés general, con noticias políticas, sociales y culturales, otras vinculadas con temáticas de salud y deporte, lo que permitió acceder a un complejo e interesante panorama sobre la coyuntura de los grupos sociales argentinos, así como alertó sobre la situación internacional. Las revistas fueron no sólo móviles de información sino también herramientas pedagógicas en los sistemas dominantes del género y la sexualidad, sostenidos y reproducidos en los discursos y las imágenes, representaciones hegemónicas, en tanto que internalizaban discursos y reproducían inercias que los lectores adquiría en la experiencia social.

Atendiendo a las representaciones femeninas en los medios de comunicación, L. Arfuch señala que estos "producen y reproducen, reflejan y transforman estereotipos, pautas y modelos imperantes, según esas tendencias hegemónicas y leyes tácitas a las que, por otra parte, contribuyen a consolidar" (Arfuch, 1996: 115). Esas imágenes que circulan "venden” otras imágenes, señala la autora, imágenes identificatorias, estéticas, valorativas. Esto nos habilita a pensar que las simbolizaciones que incurren en cómo se debe parecer, codificadas a partir del lenguaje visual, encarnan, de algún modo, el cómo se debe ser, y se convierten en indicios culturales socialmente reconocidos. Se ocupan, asimismo, de otorgar un valor de legitimidad en tanto que vienen a colmar expectativas instaladas en un contexto de demandas y exigencias sociales que concluyen en diferencias.

\section{D) Resultados y discusión}

\section{Los discursos y las pedagogías}

La relación de las mujeres con las prácticas físicas se alimentó de diferentes principios que se mantuvieron, en rasgos generales, bastante estables a lo largo de las primeras décadas del siglo XX. En este sentido estuvo patente la influencia de los discursos higienistas, eugenésicos y las justificaciones asociadas con valores de belleza.

Sin profundizar en estos principios, es importante recordar que hacia fines del siglo XIX e inicios del XX se expandieron ideas, prácticas y experiencias culturales, desde diferentes campos del saber, que procuraron contrarrestar los desvíos y los perjuicios de la vida moderna, sobre todo en la atmósfera de las grandes ciudades. En este intento vinieron las prescripciones del higienismo que buscaban velar por la salud de los ciudadanos dando impulso al uso del aire libre y justificando la virtud de sus elementos por sus beneficios terapeúticos. Se propuso la noción de cultura física, como un sistema de vida integral para mejorar la salud corporal- 
psíquica, enderezar y dominar las conductas. De la mano de estas prescripciones se conectaron los alcances del ideario eugenésico que para las mujeres tenía algunas particularidades, servía para optimizar su capacidad reproductiva cuyo fin último era transformarla en mejor madre y ayudar así a optimizar la raza del pueblo argentino (Anderson, 2015). Esto estaba hilvanado por la inclinación hacia la objetividad y racionalidad en su accionar, principios fundamentales en el campo de la medicina moderna (Di Liscia, 2003).

En este marco, se apostó por hábitos higiénicos con fines propositivos, se instó a movilizar el cuerpo, "hay que correr y saltar, no parar de correr y saltar, sino para ejercitar las grandes funciones vitales de la economía" (Romero Brest, 1903). Se corrigieron las posturas, se multiplicaron las justificaciones de la gimnasia y los deportes "como garantía de salud, educación, modelación del carácter y fortalecimiento individual y colectivo" (Anales de la Sociedad Militar, 1916).

Otra de las cuestiones fue que el seguimiento de la cultura física también tenía repercusiones en la perfección estética. Dado que se creía que todos los problemas de la belleza —salvo los trastornos de nacimiento- provenían de la falta de salud, ${ }^{6}$ conservarla garantizaba alcanzar el atractivo físico tan deseado por los grupos femeninos. Los movimientos eran la base de la educación estética de la mujer, daban al cuerpo una formación más completa, regularizaban el sistema nervioso, desarrollaban los hábitos motores y contribuían a establecer el carácter, así como ayudaba a conservar y potenciar la gracia y la elegancia.

No todas las prácticas gozaban de la misma aceptación. Sobre la natación, algunos médicos y conservadores concluían que las mujeres eran biológicamente inferiores e incapaces para nadar, especialmente en aguas abiertas, frías y agitadas, porque se requería esfuerzo físico extremo y esto podría dañar permanentemente las constituciones de las mujeres, como el útero, haciendo que las mujeres se volvieran "sin sexo". ${ }^{7}$

En estos discursos hay una fijación del sentido por la condición biológica. La función femenina de reproducir parecería ser la garantía de la opresión, y su genitalidad un dispositivo regularizador y normalizador. Se apelaba a la naturaleza para sostener la desigualdad en el acceso a la práctica.

Estas construcciones se fundaban en características estereotipadas. Los valores como el coraje, la fuerza, la energía, la confianza en sí mismo, la ambición y deseos de liderazgo, eran cualidades que identificaban al ideal del varón deportista (Scharagrodsky 2002-2003) poco deseables para las mujeres. El temor residía en virilizar al sexo débil, contrariar las formas honradas de su carácter y de su apariencia, perturbar los comportamientos entendidos como femeninos, universales y escencialistas para todas las mujeres, sin dar lugar a la individualidad o la discrepancia. Resonaba la inquietud por desestabilizar un sistema afirmado en las desiguales relaciones de poder entre los sexos, por alterar las estructuras que durante largo tiempo identificaron las incumbencias de los géneros, socialmente sostenidos.

A pesar de las negativas, la natación fue ganando adeptos, y ninguna opinión ponía en duda su utilidad en la vida cotidiana. En este sentido, las fuentes coinciden en señalar que aprender a nadar era una medida que salvaba del ahogamiento a las mujeres y a los niños de la nación. ${ }^{8}$

Desde las alabanzas de las miradas científicas, fisiológica e higiénica, se argumentó que la natación representaba un sinnúmero de ventajas. Al tener como objeto que el cuerpo se mantenga en la superficie del agua, era un ejercicio fortificante y completo para el desarrollo de la motricidad, la musculatura, una postura correcta y el estímulo de una respiración eficiente. $\mathrm{Al}$ mismo tiempo, su efecto relajante descongestionante permitía controlar y quitar la tensión del sistema nervioso, ayudaba a desarrollar aptitudes mentales sanas de coordinación de cuerpo y mente (Diccionario enciclopédico hispano-americano de literatura, ciencias y artes, 1887-1910). Además, era una práctica de ocio y sociabilidad, en varios tópicos de la prensa se refieren a la natación como uno de los pasatiempos más agradables y más higiénicos para el verano, como un alivio a las condiciones opresivas del calor para todas las edades y ambos sexos.

Algunos discursos se apegaban a destacar los efectos estéticos de la práctica, como la gracia, la armonía, la belleza, la elegancia al sugerir que una mujer nadando no era un ser vulgar y en la natación cabían tantas coqueterías y tantos refinamientos como en el andar a pie en tierra firme (Caras y Caretas, 1905). 
Con marcado interés por hacer extensivas las formas de disciplinar los cuerpos, en la prensa se incluyeron algunas indicaciones cuasi técnicas de los procederes. Las primeras se ven en niñas y niños, dado que se suponía que en la infancia habría mayor entusiasmo para estas actividades que en la adultez. Estaban quienes preferían el aprendizaje dentro del agua, con la ayuda de un instructor o con ingeniosos instrumentos para comandar las posiciones del aprendiz.

Una de las teorías más aceptadas era nadar "en seco", con el fundamento de que había que saber sumergirse en el aire antes de hacerlo en el agua. Para ello, algunas señoras acudían a casa de los "profesores de belleza" para que les enseñaran y también se las animaba a permanecer en sus casas implementando recursos domésticos:

(...) todo el mundo sabe que la natación es un sport excelente no es menester salir de casa ni siquiera de mojarse para disfrutar de sus beneficios: basta con apoyar la parte anterior media, del cuerpo sobre un taburete y de hacer los movimientos del que está realmente nadando. (Caras y Caretas, 1911)

Estas rutinas siguen en el tiempo y se van extendiendo en revistas especializadas sobre salud y deporte. Las aspiraciones eran grandes, se aseguraba que nadar era tan fácil en la teoría como en la práctica que lograrían nadar tan bien en el agua, aún si no lo hubiesen ensayado antes. Curiosamente se animaba a practicar la respiración sin que sea necesario meterse al agua, pudiéndose hacer en el baño o en el lavatorio.

Las descripciones técnicas de los movimientos se volvieron más minuciosas. Se insistía en la actividad hecha a conciencia, con voluntad y concentración, donde nada debía quedar al azar. El acento estaba puesto en la intensidad, regularidad, constancia y esfuerzo como medios para sacar el mejor provecho. Esto dotaba a las mujeres de un tipo de autonomía personal que difería en parte de las actividades que realizaban habitualmente. Hay aquí una voluntad por generar conciencia del cuerpo y de sus emociones que comienza a instalarse en algunos grupos. Esto no es extensible a todas las capas sociales, habrían sido, en los inicios, los grupos medios y más privilegiados quienes tuvieron el acceso a la enseñanza.

FIGURA 1

Enseñanza práctica de la natación. (8 de febrero de 1902). Caras y Caretas, s/p.

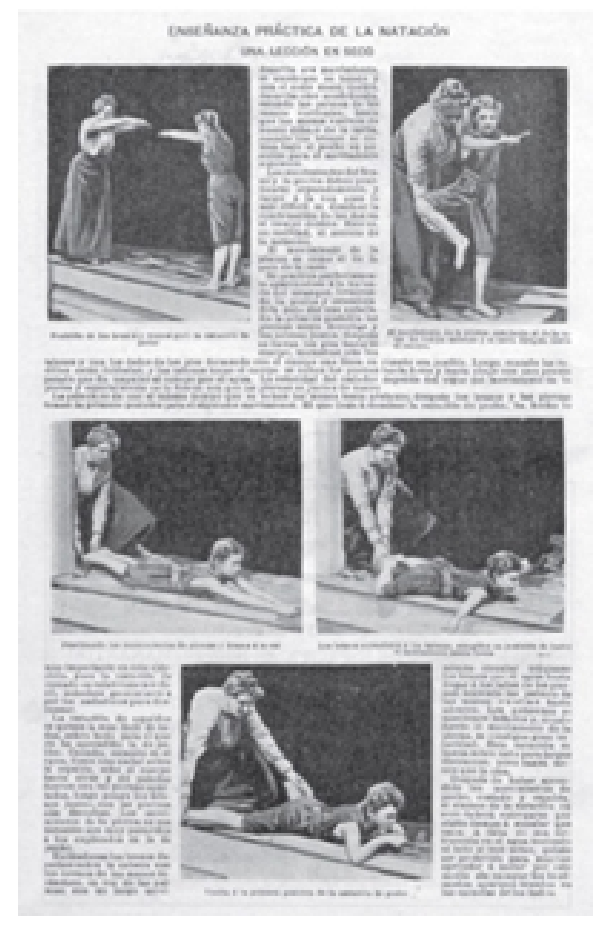


FIGURA 2

Breves lecciones de natación. (25 de mayo de 1926). Fray Mocho, s/p.

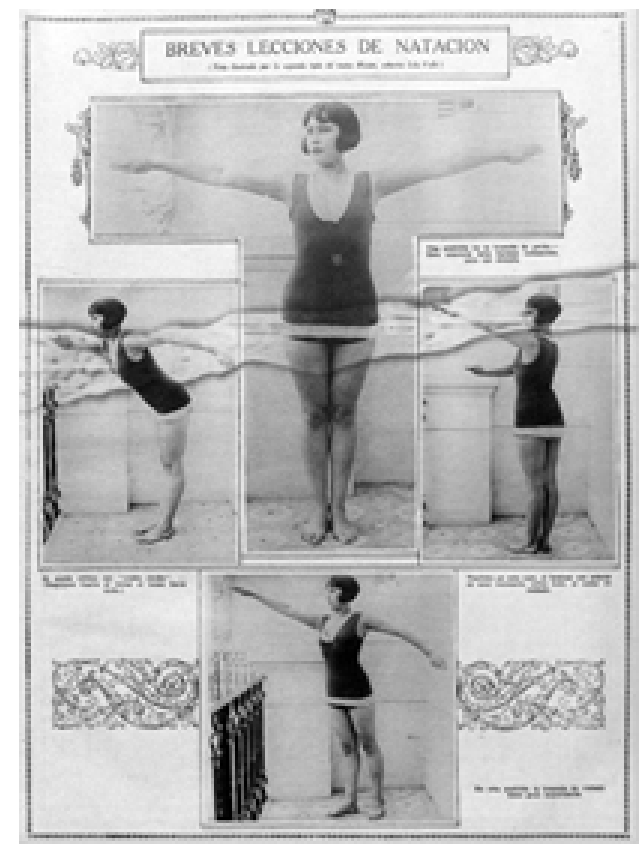

FIGURA 3

¿Sabe usted nadar? (5 de febrero de 1941). Viva Cien Años, p.608.

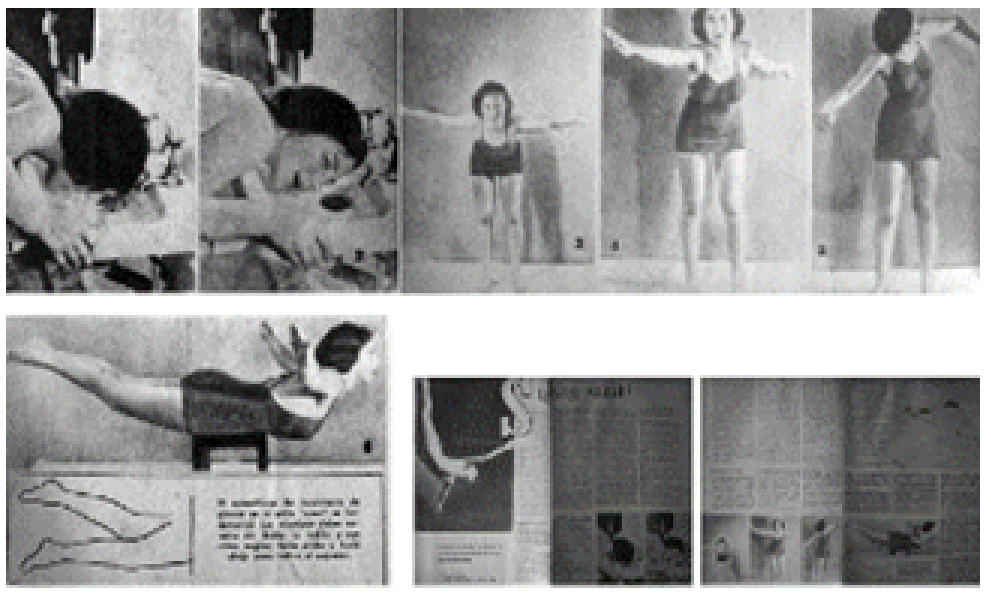

Puede verse en las imágenes que la representación del cuerpo complementaba la abstracción de las palabras, dando ideas generales de las performances. En sus inicios eran exiguas y tenían sus limitaciones por la falta de detalles de los grabados, con la fotografía esto se mejoró. Se transmitieron instantes de maniobras básicas como fragmentos de una serie de rutinas y estilos que la lectora debía ajustar (Figura 1, Figura 2, Figura 3).

Estas pedagogías, como se anticipó, devenían de discursos transnacionales, europeos y norteamericanos, siendo numerosos los esquemas técnicos de posiciones y destrezas que proliferaron en diferentes medios letrados y visuales. Tanta afinidad parecía haber tenido en la cultura moderna que desde diccionarios y manuales para aprender a nadar hasta postales y fotografías, incluso en objetos de consumo superfluo como las tarjetas de cigarrillos -en coleccionismo conocido como cartofilia- llevaron ilustraciones sobre natación que permitían una aproximación a los tipos dinámicos (Helfand, 2008). Mujeres y varones eran protagonistas (Figura 4- Figura 5-Figura 6). 
FIGURA 4

French dictionary: Nouveau Larousse Universel, 1948

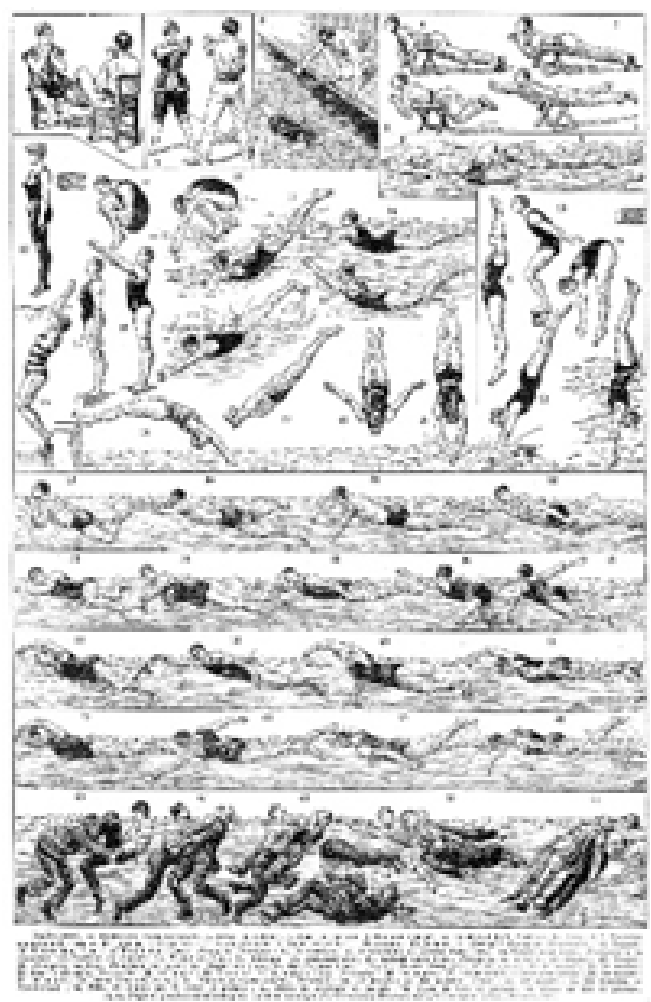

FIGURA 5

Leçon de natation. La brasse. France, 1942. Photo en vente sur le site de Paris en images.

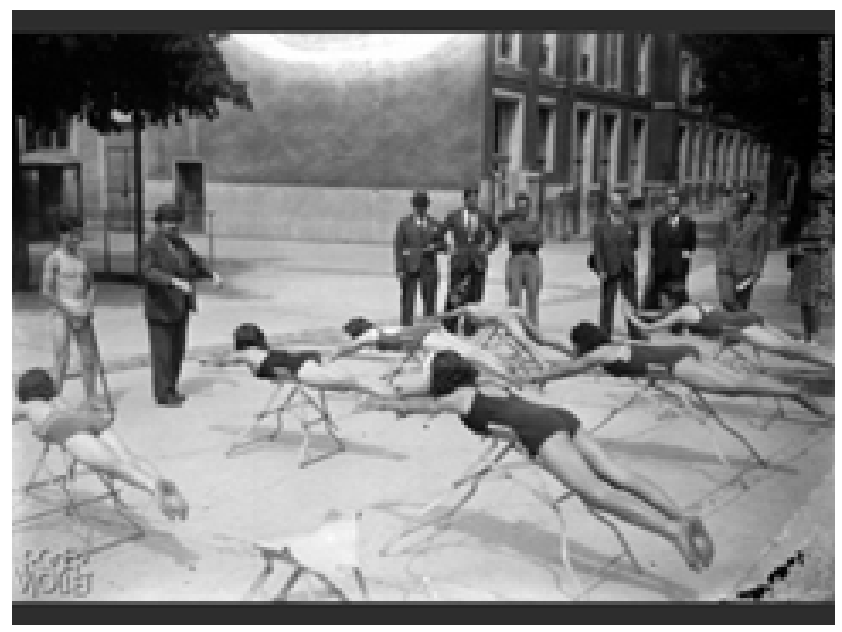


FIGURA 6

Ogden Swimming Instruction Cards, 1930

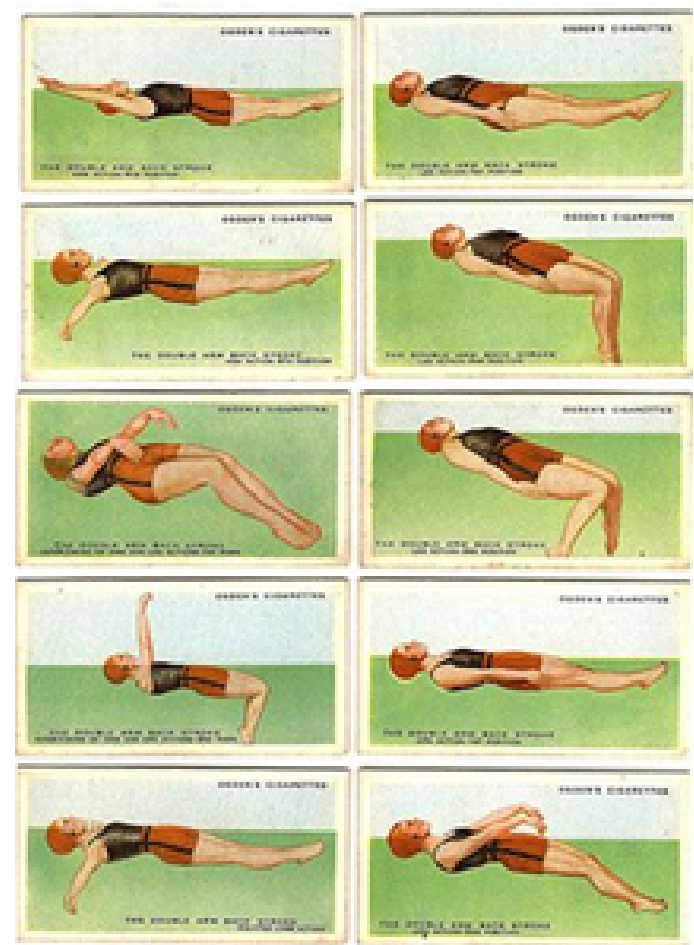

Un personaje que las crónicas mencionan como clave en la expansión de la natación femenina fue la australiana Annette Kellerman (1886-1975). Inició la práctica siendo niña por una recomendación médica, logró ser pionera en nado sincronizado a nivel profesional y creadora de un sistema de gimnasia. ${ }^{9}$ Estas experiencias, le permitieron vincular el deporte con la salud y la belleza, de modo que legitimó el nado como un ejercicio embellecedor y apropiado para las mujeres.

Fue considerada "la más cercana a una mujer perfectamente proporcionada" (The New York Times, 1910) cuando un experto en acondicionamiento físico de la Universidad de Harvard tomó sus medidas. El profesional estudiaba las características físicas de la mujer moderna para verificar si se estaban volviendo más masculinas. En sus resultados concluyó que, si bien las proporciones habían cambiado, presumiblemente como resultado del mayor ejercicio físico, era un cambio para mejor y Kellerman era el ejemplo. En Argentina, el evento fue referido en la prensa y allí, en palabras de la nadadora da una serie de recomendaciones saludables para que las mujeres adopten en la vida cotidiana. Si bien, de acuerdo con las fuente no fue feminista en términos políticos, sí se preocupó por dar a las mujeres estrategias para empoderarse, para ejercer el control del cuerpo, ser más independientes y con ello redimir, en algunos aspectos, su inferioridad social.

Lo interesante de su figura es, por un lado, el modo de combinar los requerimientos del deporte como la exigencia de un buen estado físico y determinación, con el atractivo sexual femenino, dado por la gracia en sus movimientos gimnásticos y su comportamiento personal virtuoso -aún habiendo participado en el cine y en el vodevil. Esta habría sido una manera culturalmente apropiada para divulgar la práctica, su ejemplo habría alentado a otras mujeres a aprender a nadar y el manual de natación ilustrado habría sido un medio para lograr mayor alcance (Figura 7).

Por otro lado, lo que interesa es reconocer que parte de su trascendencia en el mundo del deporte estuvo dada por su desigualdad con los varones nadadores. Es decir, es una figura que resaltó porque no reprodujo las lógicas, porque abrió espacios y deslimitó otros donde la figura del varón era el referente privilegiado. De ahí su reconocimiento en numerosos documentos de la época y aún en la actualidad, por ser una excepción. 


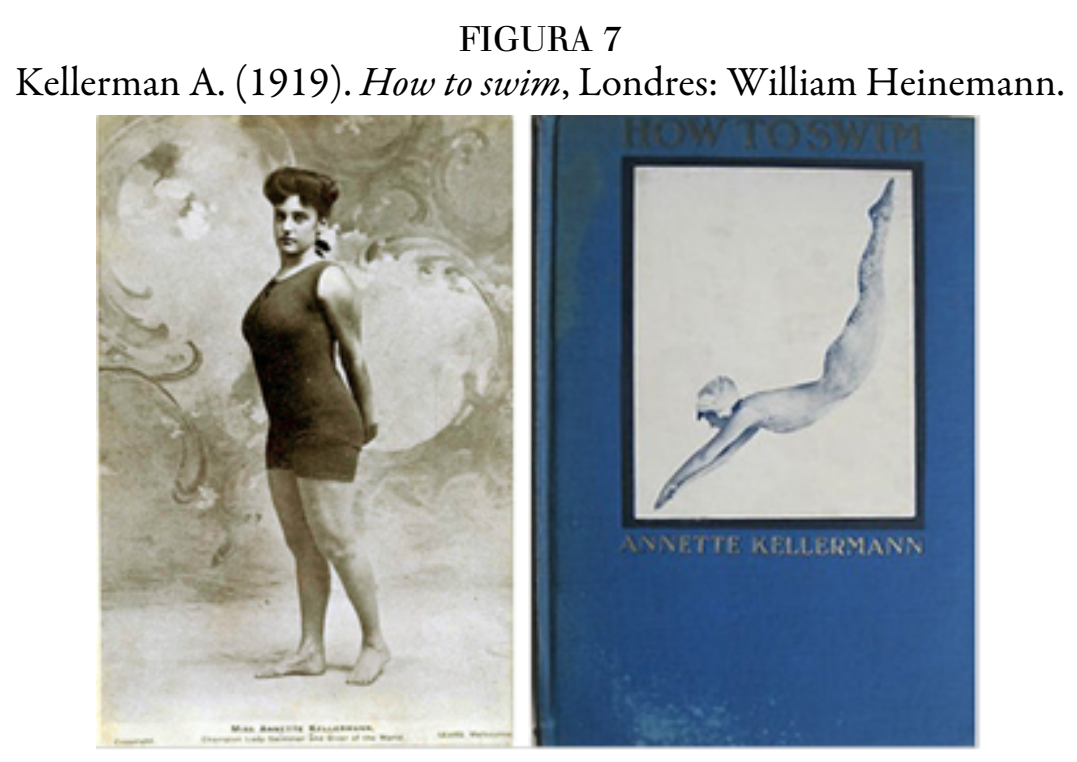

Una de las repercusiones positivas del desarrollo de la natación, nada fortuita, que puede cotejarse en la cronología de las imágenes, es la simplificación del traje de baño. A medida que los reformadores defendían los beneficios para la salud del ejercicio moderado para las mujeres a principios del siglo XX, algunas voces comenzaron a exigir la reforma de esta indumentaria dado que era un impedimento que podía conducir al ahogamiento. En lugar de vestidos en capas con faldas voluminosas, cinturas apretadas y enaguas, los reformadores propusieron que las mujeres usaran una prenda holgada de una pieza, similar al traje de baño usado por los varones. Kellerman fue parte de este cambio porque ella misma tuvo que diseñar un traje ajustado y aerodinámico que mejorara su rendimiento en el agua y que le permitiera competir en condiciones más igualitarias con sus contrincantes varones.

Más allá de que esto propició virajes en las condiciones estéticas en términos de la moda y que los cambios resultaron prágmáticos como tema de salud pública que permitió a las mujeres tener mayor control de sus performances, es interesante pensar este proceso desde la perspectiva feminista en los siguientes términos. La forma de cubrir el cuerpo de la mujer en el agua, inicialmente, se correspondía con las ideas de feminidad más que con los requerimientos funcionales porque la incomodidad tenía sus bases en argumentos culturales y subjetivos sobre la moralidad, el pudor y la virtud. Por su parte, los varones podían sacar provecho de la agilidad y la vocación en el desempeño exitoso del deporte, sin que el vestido restringiera sus habilidades.

\section{Nuevas experiencias}

Como se anticipó sucintamente, la movilización del cuerpo en el agua fue promovida por las miradas médico-higiénicas en sus inicios, pero pronto pasaría a ser también, un estímulo de experiencias lúdicas en el marco de transformaciones de carácter urbano y cultural en las ciudades.

Las fuentes consultadas marcan que con la introducción de la natación en Argentina por parte de nadadores inmigrantes británicos - que fundaron el "Dreadnought Swimming Club" en 1863-, comenzaron a realizarse las primeras reuniones con popularidad entre el público. Todos los sábados antes de la hora del té se celebraban carreras que no excedían los $100 \mathrm{~m}$., los primeros antecedentes de la disciplina como deporte y espectáculo (Soto, Meloni, Gaiarin, 2011). Algunas competencias se realizaron en el Riachuelo porteño y luego se construyó un natatorio cubierto (1870) que posibilitó el nado en todas las épocas del año.

El interés por estas prácticas se extendió rápidamente y la construcción de piletas se fue replicando ${ }^{10} \mathrm{y}$ para mediados de la década de 1930 había cuarenta instituciones con amplios natatorios (Caras y Caretas, 
1936). ${ }^{11}$ Se fueron construyendo piletas públicas y privadas en parques, clubes, balnearios y en terrenos o propiedades baldías en Buenos Aires y sus alrededores.

Algunas piletas tuvieron la doble finalidad de ofrecer educación deportiva y recreación, con estas obras, se legitimó el papel de organismos del Estado y asociaciones privadas en la promoción y fomento de programas para atender la salud y la integración social en las ciudades, un recurso que servía para inculcar hábitos higiénicos, a la vez que se aseguraba un empleo positivo del tiempo libre de los grupos que quisieran gozar de los beneficios del agua y del deporte.

El dictado de clases estuvo marcado por un uso específico que no escapaba a las regulaciones entre los sexos, estaba la disciplina de una institución, la ley para regular la diferencia y el orden. Generalmente la mañana se reservaba para señoras, niñas y niños, de tarde podían concurrir mujeres adultas y varones. El precio de la entrada con baño, ropa y en algunos clubes con acceso a los juegos gimnásticos, era accesible, se alquilaban vestidos de baño que las mujeres podían usar y devolver después de sumergirse en la pileta. En algunas piletas se recibían lecciones de natación por personalidades conocidas como el campeón mundial Enrique Tiraboschi, que la prensa elogiaba.

Además de estas rutinas, en las piletas se celebraron competencias, carreras de largo, concursos de zambullida, pesca de platos, experimentadas como verdaderas fiestas, no sólo por la cantidad de público que asistía sino por la euforia con la que se vivía. Y se conectaron una serie de actividades culturales, muchos eventos e inauguraciones se dieron allí, incluso desfiles de moda luego de exhibiciones de natación. Si bien la concurrencia era de ambos sexos, quienes desfilaban en traje de baño eran las mujeres, situación nada casual dada la naturalización o esencialización de que a todas las mujeres debían interesarles los temas de moda y los varones se entretenían con el espectáculo.

Si bien hacia 1920 las crónicas aseguraban que adquirían cada día más interés e importancia las pruebas de natación en las que competían sólo aficionadas mujeres, habría sido hacia la década siguiente cuando se dio mayor auge. De acuerdo con los estudios de Vigarello (2007), Lipovetsky (2002) y Featherstones, Hepworth y Turner (2001), entre otros, las nociones de delgadez y juventud se situaron en el eje de la atención, el imperativo de la línea y la esbeltez se convertiría en un motor para agilizar los cuerpos femeninos e imprimir nuevas rutinas que combinaran la disciplina con el placer. Esto proliferó en un contexto en el cual el impulso al ocio y al turismo consolidó nuevas experiencias del cuerpo en espacios naturales, como los balnearios de mar.

En ese momento, más que antes, el deporte servía como medio para alcanzar la perfección, procurar belleza y, no menos importante, alargar la juventud. Era la representación de la mujer moderna. Esto vino a confirmar un nexo diferente entre bienestar y belleza, se trataba de un cuerpo que gozaba de las sensaciones provocadas por el ejercicio, no solo por sus efectos reparadores y estéticos sino, también, por ser una fuente de placer y diversión, teniendo en cuenta que eran vacaciones, podrían olvidarse que esos movimientos eran ejercicios.

Los ojos curiosos de la prensa difundieron la atmósfera social de las mujeres en los clubs sportivos y balnearios de cada provincia o localidad y con sus discursos visuales y verbales exaltaron sus rasgos de feminidad (Figura 8- Figura 9):

(...) esta elocuente foto, tomada al borde de una pileta, podría servir de símbolo moderno del calor. Mallas ajustadas ciñendo formas juveniles, grandes sombreros protectores y sonrisas optimistas en todos los rostros: he aquí la síntesis de una pileta de hoy" (Caras y Caretas, 1935).

La cita pasa por alto el valor del deporte, en todo caso refuerza el estereotipo atractivo heteronormativo.

La construcción de las feminidades respondió a un repertorio kinético específico, a ciertos gestos, posiciones, desplazamientos y formas de pararse o sentarse tendientes a la moderación, a la provocación de simpatía. Se las ve lucirse para el fotógrafo como podrían hacerlo en otro evento pero, en este marco, se añadía la visibilidad del cuerpo, el traje de baño delataba los contornos y provocaba a la fantasía. 


\section{FIGURA 8}

En las piletas de natación comienza la ofensiva contra el calor de verano. (21 de diciembre de 1935). Caras y Caretas, s/p.

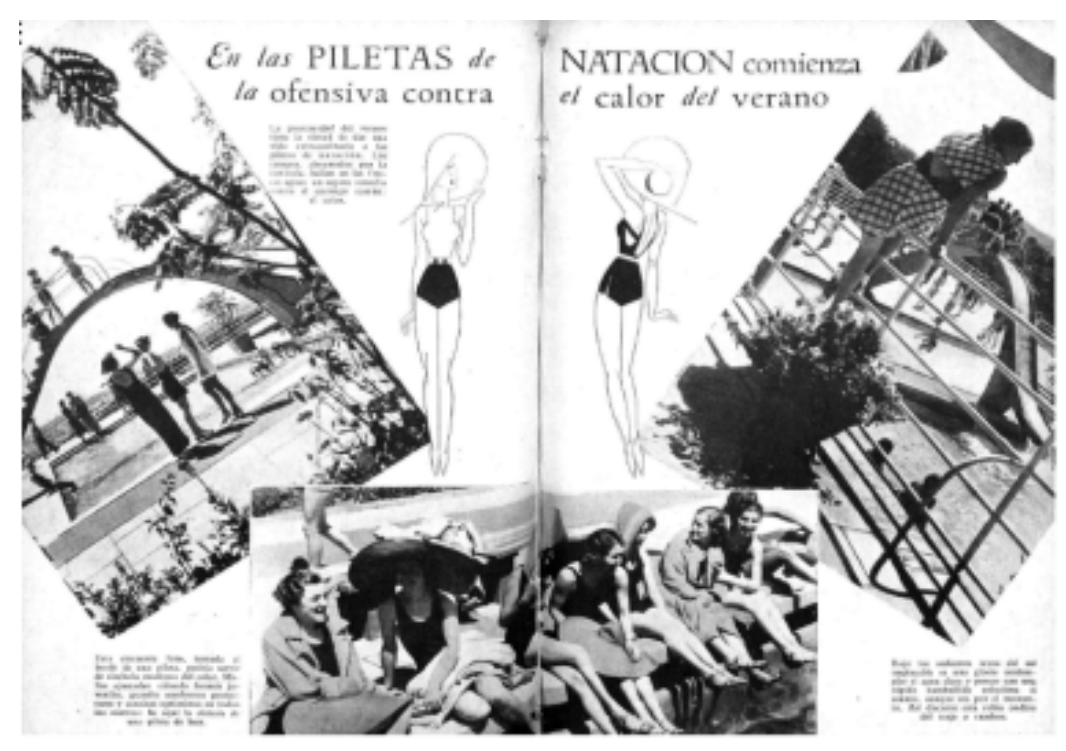

FIGURA 9

En la pileta de natación. (noviembre de 1926). Plus Ultra, s/p.

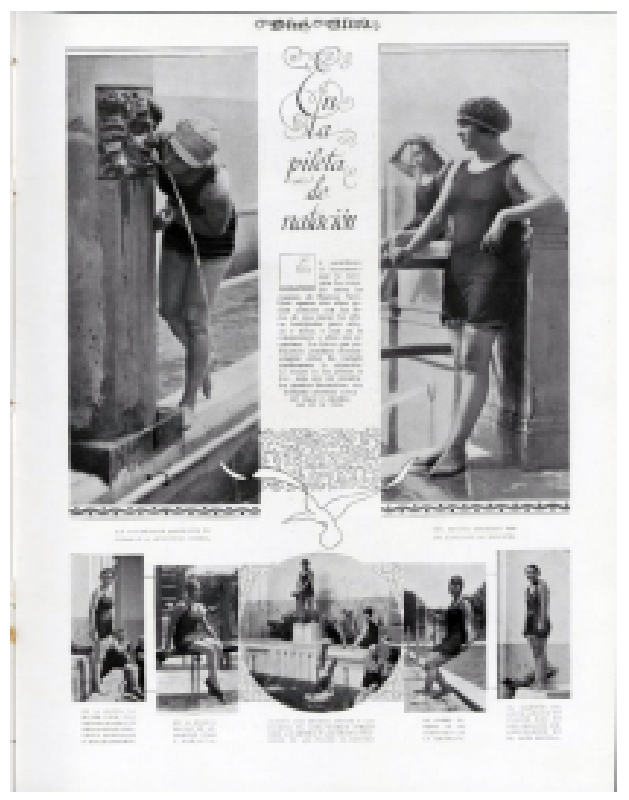

Berger analizó con precisión estas modalidades de darse a ver y sugirió, entre otras cosas, que las mujeres más que los hombres ven sus cuerpos como objetos a los cuales se ha de mirar y de apreciar, no porque lo femenino sea distinto a lo masculino, sino porque siempre se supone que el espectador 'ideal' es varón y la imagen de la mujer está destinada a adularle (Berger, 2000:21). La dominación masculina de la que habla Bourdieu, convierte a las mujeres en objetos simbólicos percibidos porque existen fundamentalmente "por y para la mirada de los demás” (Bourdieu, 2000: 86). Se espera de ellas que demuestren cualidades de feminidad, que se presenten sonrientes, sumisas, discretas, que gusten y seduzcan como una forma de complacencia respecto a las expectativas masculinas. Estos dispositivos visuales difundidos en la prensa jugaron a favor del deporte como medio para la estilización estética y, en este sentido, introdujeron dosis de seducción en un marco que gozaba de cierta legitimidad. Se plasma con total nitidez la relación entre este repertorio kinético 
y las imágenes del cine, forma cultural sumamente revolucionaria para la inclusión de estereotipos de género deseables. ${ }^{12}$ Da la sensación que el deporte era una excusa para exhibir cuerpos bellos a la mirada de los demás.

En muchas de estas notas los epígrafes se entretienen con las semejanzas de las muchachas como ondinas, ninfas y sirenas, seres acuáticos que en la mitología griega estaban caracterizados por su capacidad de seducción, que cautivaban a los varones hasta el punto de provocarles la muerte. Desde la teoría feminista la forma de poner en narración es performativa, en el acto de nombrar se construye el sentido, se diseñan las identidades, es así como las formas de inteligibilidad de los géneros también se construía desde las formas de exponer el cuerpo hasta las palabras que adjetivaban a las mujeres.

No todas las identidades eran iguales ni lucían igual. Pensando desde la interseccionalidad, el uso de las piletas estaba ajustado por el género y también por la condición de clase. Aunque entre las aspiraciones del deporte moderno estuviera la voluntad de desmarcar las desigualdades, no puede escapar de las determinaciones sociales que reintroducen en un campo supuestamente impermeable, cada uno es portador de una identidad social fuerte y específica (Chartier y Vigarello, 1982:291) que depende del poder económico cultural y del tiempo libre (Bourdieu, 1992: 178). Los usos de las piletas municipales, las de los clubs sportivos y las piletas de las viviendas particulares marcaban un acceso selectivo y permitían opciones segregadas de la actividad de los otros, asociado con una forma de ser corporal y la gestualidad como signos de desigualdad (Figura 10-Figura 11). Las piletas municipales con gran participación en las reuniones de domingo se caracterizaban por el bullicio, la informalidad, el desorden del entretenimiento, la convivencia entre sexos con pocos distanciamientos y protocolos de buenas costumbres, algunos en grupos de conocidos, otros, conviviendo con las multitudes de cuerpos anónimos y poco vestidos.

Por su parte, el lujo de poseer una pileta para ciertas familias porteñas con aspiraciones de aristocracia, estaba respaldado por un uso privado. La concurrencia y las relaciones entre los sexos se daban en el entorno de la intimidad, de vínculos afectivos, familiares y amicales, eran pasatiempos de mujeres y varones ociosos que perfilaban la categorización de un estereotipo excluyente en busca de distinción. Algunas de estas quintas y residencias de veraneo en San Fernando, San Isidro, El Tigre fueron quedando en desudo, se vendieron o subdividieron sus lotes cuando las playas marítimas, especialmente Mar del Plata colmaron las expectativas de la concurrencia.

FIGURA 10

Una tarde en los clubs sportivos porteños. (13 de enero de 1936). La Nación, s/p.

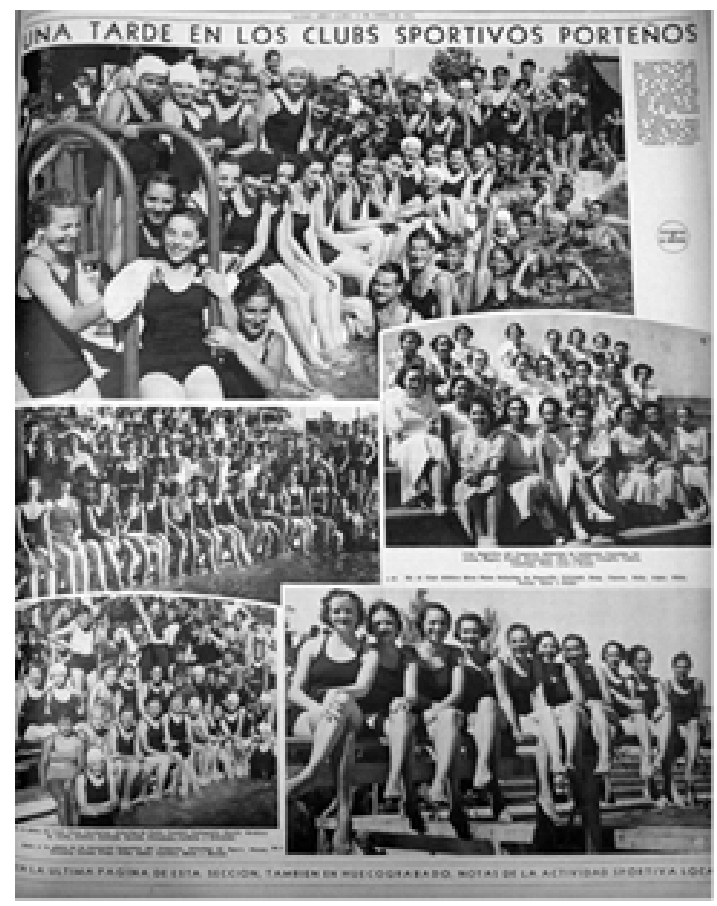


FIGURA 11

La pileta de natación de la señora Candelaria F. de Duhau. (2 de febrero de 1929). Caras y Caretas, s/p.

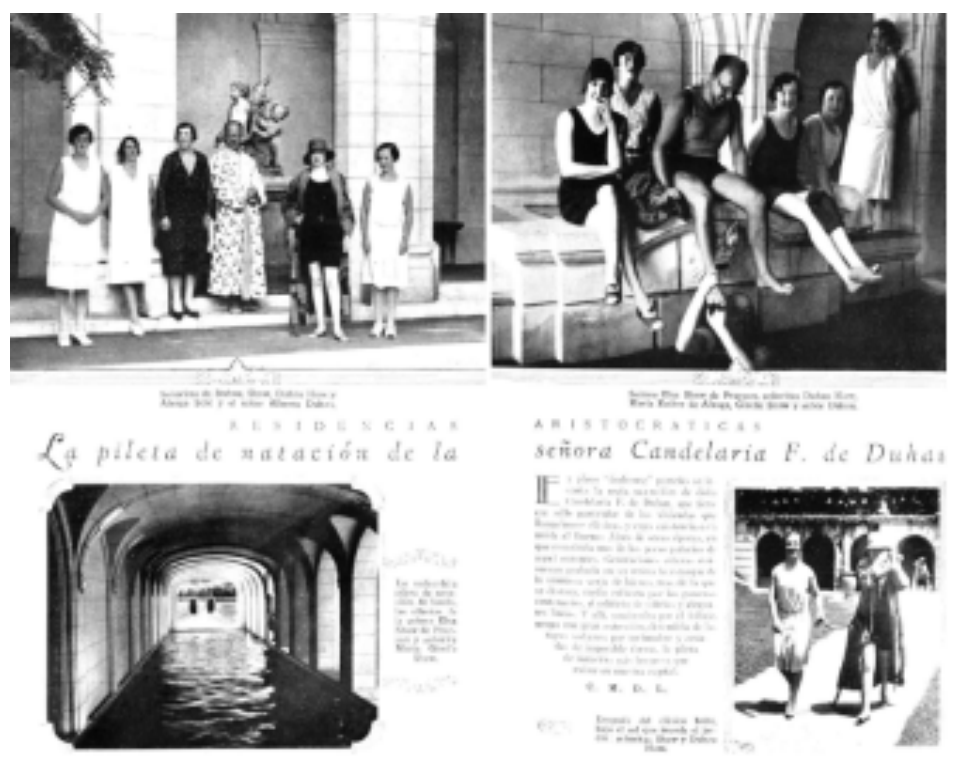

\section{Competición}

En sincronía con estos procesos, se incorporaron propuestas en las cuales el deporte adquirió un carácter definido:

Antes se practicaba para divertirse, y hoy se ha hecho de él una profesión. No había más que amateurs, hoy todos quieren ser campeones [...] que bien pudieran dar [...] fama, dinero y quizá, un contrato ventajoso para el cine [...] ser una estrella de la pantalla en el cielo de Hollywood (Caras y Caretas, 1929).

Esta cita da cuenta de cómo se van ampliando las aspiraciones de las aficionadas a los deportes y las ventajas materiales e intangibles que se transmitían, al punto que la cronista termina su nota preguntándose por qué no le habrían enseñado a usar la raqueta en vez de a escribir, dada la trascendencia que parecía tener una profesión en comparación con la otra.

La mención de mujeres en competencias tuvo algunos antecedentes sobre el inicio del siglo pero con características bien distintas. En el contexto de notas periodísticas sobre hazañas, carreras, campeonatos y pruebas salpicaron las páginas algunas escenas y nombres de ciertas mujeres que comenzaban a competir contra los hombres en el extranjero. En Argentina, ganaron popularidad hacia la década de 1920, las hazañas como el cruce del Canal de la Mancha realizado por Enrique Tiraboschi, la medalla de oro obtenida por Alberto Zorrilla en los Juegos Olímpicos de 1928 y el primer cruce del Río de la Plata logrado por Lilian Harrison, en 1923, una de las primeras actividades a través de las cuales las mujeres argentinas hicieron su irrupción en el deporte profesional. Lilian Harrison (1904 - 1993) fue precursora de la difusión de la natación en Sudamérica, nacida en una familia inmigrante británica se trasladó de niña a Inglaterra para educarse y allí aprendió a nadar. Al regresar al país en la década de 1920 continuó su entrenamiento en el Club Náutico San Isidro con destacados profesores, lo que le permitió prepararse para cruzar a nado el río más ancho del mundo y establecer un récord mundial femenino de permanencia en el agua.

Parecería que el auge de las Olimpíadas en Alemania en 1936, en la que participó la argentina Jeannette Campbell (1916-2003), habría influenciado en el aumento de completos reportes de diferentes disciplinas generando gran entusiasmo en las aficionadas y difundidas ampliamente en la prensa con números especiales. 13 Se destacaron biografías sobre nadadoras consumadas como Dora Rodhius, Inés Milberg, Marjori K. Seaton, Ursula Frick, Amelia Rubio, Noemí Orstadius, Estrella E. Iglesias, Susana Mitchel, Margarita 
Talamona, Elena Tuculet, entre otras. En las revistas se celebraron las cualidades sobresalientes, empleando adjetivaciones más vale neutras en el sentido que se admiraba la contracción al entrenamiento, la dedicación, el prestigio derivado de la regularidad de las performances, eran referentes que abrían oportunidades sin implicar condicionantes de tipo sexual. Se trata en estos casos de relatos con códigos del periodismo deportivo, aunque las fotografías -en ocasiones- no dejaran de enfatizar características corporales (Figura 12, Figura 13).

El deporte como práctica sistemática promovía vivencias extremas, situaciones no calculadas, movimiento constante, todas características que no eran propias del esquema que producía y reproducía el contrato social para el cuerpo femenino, el punto de referencia del modelo androcéntrico en el campo del deporte era el varón, por lo cual se tendía a desvalorizar las prácticas del otro -la mujer-. Si el cuerpo es un medio que permite alcances, potencias y logros que modifican la anatomía con marcas específicas, los patrones sociales parecían desestabilizarse cuando en las mujeres prevalecían signos referidos a la virilidad, evocadas tradicionalmente desde parámetros formulados a partir de la debilidad, la fragilidad, lo inmóvil (Salazar y Manzo Lozano, 2009), asociadas con los estereotipos vistos en el apartado anterior. En este sentido, si la actitud era de esfuerzo y compromiso en acción clasificarlas como "sexo débil" era una verdadera ironía, ya que las competidoras "hacían derroche de sangre fría y destreza tanto como lo pudiera hacer el más eximio y arrojado representante del sexo fuerte" (Caras y Caretas, 1921).

En el plano estético la práctica sistemática del deporte traería sus consecuencias negativas en algunas opiniones. En la prensa europea, por ejemplo, se hablaba de los efectos del deporte profesional como causante de otras formas de corporeidad de la mujer, ¿los cuerpos se han vuelto menos femeninos? era la inquietud principal. Algunas mujeres se afiliaron a un estereotipo que ciertamente se asemejaba a la apariencia masculina. Los rasgos de su corporalidad, el lenguaje de los gestos y la indumentaria de malla sumaria contribuían a que los atributos sensuales se disiparan refiriendo una feminidad transgresora que reflejaba las consecuencias de la funcionalidad de ejercicios sistemáticos.

Sin embargo, quienes estaban a favor de los deportes apuntaban a la idea de que se trataría de una forma de belleza nueva. Y en este sentido, la natación de competencia tenía algunas ventajas frente a otros deportes. Es interesante desandar la persistencia de estrategias narrativas y visualidades para acentuar lo femenino, muchas veces con imágenes a página completa que dan lugar central al cuerpo. Así, las nadadoras era consideradas una belleza artística, y quizás más en el momento de los saltos ornamentales:

En ninguna rama del deporte como en la natación, se destaca la gracia y armonía de los movimientos femeninos y más aún en el difícil arte de zambullir (...) en el instante en que plasma una delicada expresión, modelada en el aire con los contornos de su silueta estilizada, que adquiere belleza incomparable en la rítmica caída (Caras y Caretas, 1938).

Las sensaciones que las imágenes transmiten conjugan la habilidad técnica y el dominio del cuerpo, de su disciplina y sus resultados de constitución corporal, y también la plasticidad que pone el acento en la esbeltez, en la línea, la tensión muscular, el equilibrio y la coordinación (Figura 14). Semejante apreciación puede hacerse en el cuerpo masculino, pero pareciera que las variables asociadas con la belleza se imponen como exclusivos de las mujeres. 
FIGURA 12

Imagen de portada. (6 de enero de 1939). El Gráfico, s/p

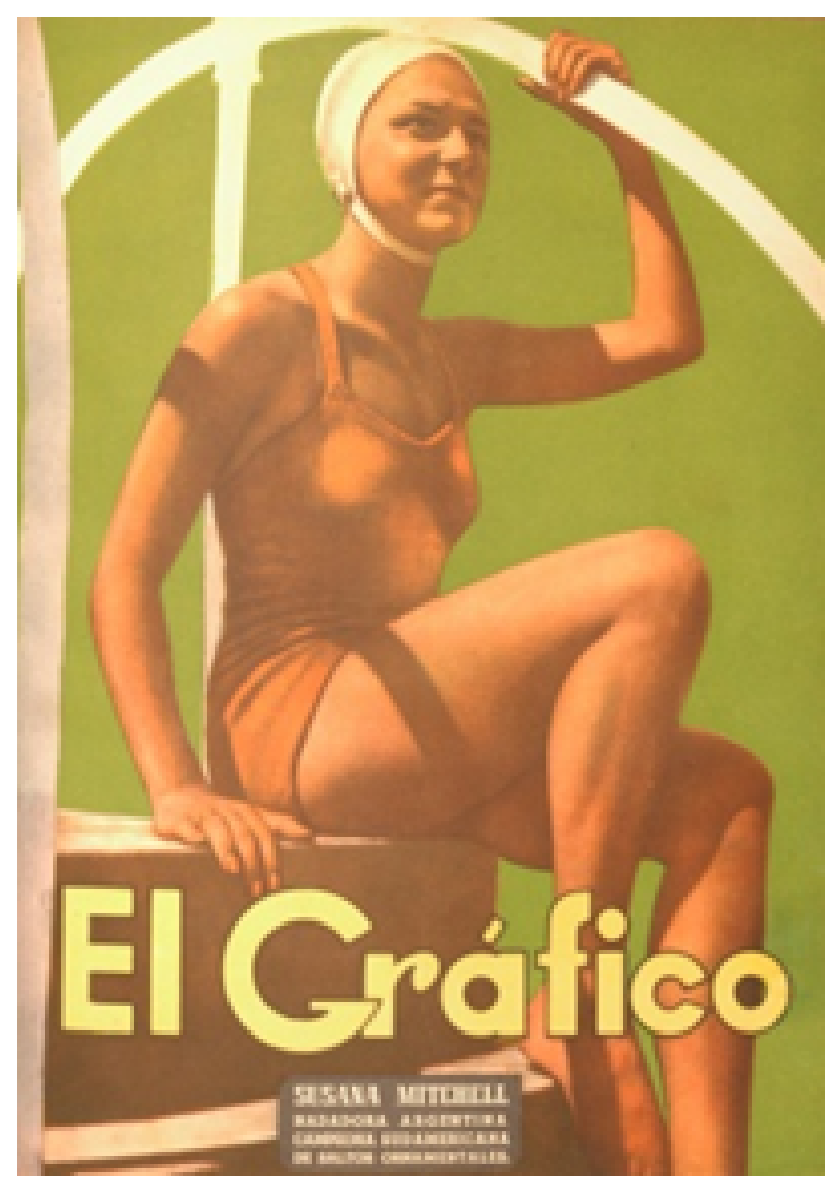

FIGURA 13

Torneo Panamericano. (27 de enero de 1939). El Gráfico, s/p.

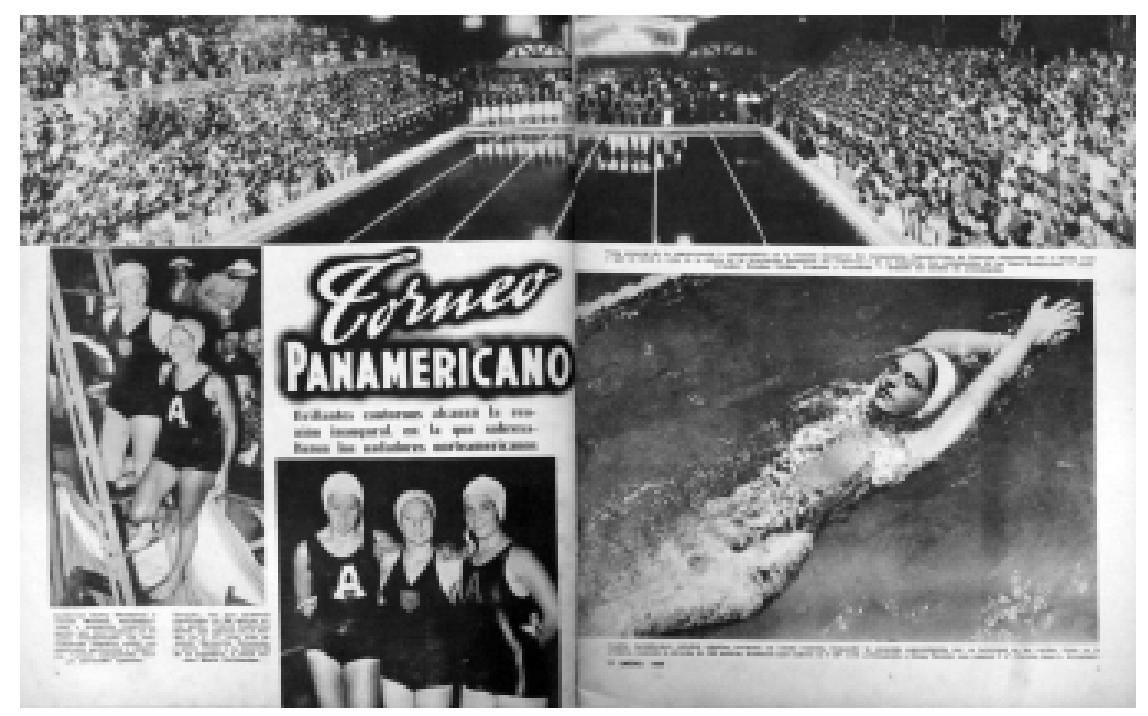


FIGURA 14

El arte de la zambullida. (27 de agosto de 1938). Caras y Caretas, s/p.

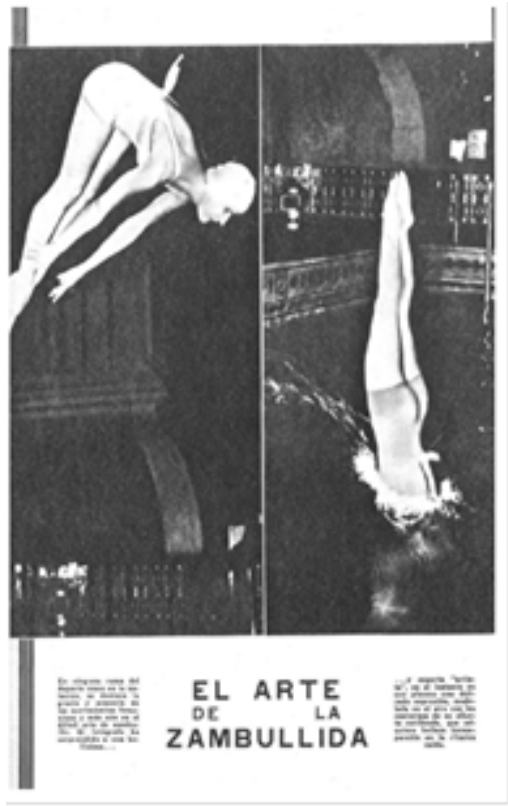

Estas representaciones no fueron inocentes. Las representaciones gráficas que crean los medios de comunicación sintetizan a través de signos reconocibles, de manera simplificada, ordenada, coherente, una imagen para referirse a un conjunto de significados. Instalan los estereotipos que lejos de ser objetivos son construcciones sociales que por repetición, determinan características y atributos asociados a determinados grupos para orientar ideas, pensamientos e imaginarios. Por esta razón se articulan con posicionamientos estéticos y corporales, ideológicos y morales de aquello que representan y lo hacen extensible a las identidades de quienes los adoptan, impidiendo la posibilidad de ignorarlos o ponerlos en duda.

Lo que se muestra, lo que se ve es lo que está dentro de una norma, lo que incluye, da legitimidad, produce deseo, no necesariamente valores positivos a quienes lo siguen. Por el contrario, lo que se invisibiliza en los estereotipos queda como anomalía y estigma, produce rechazo, limita la libertad de elección (Dominguez, 2019). Así, en el registro efectuado se ve que, con prudencia, se van penetrando modelos nuevos que tienden a instalar versiones dispares de lo femenino. No por eso menos estables o menos válidas. Quizás algunas de estas sean imágenes que anticipen realidades, justamente en este proceso reside lo significativo.

Hay un diálogo entre exaltar el lenguaje corporal propio del deporte y el de las ligazones con formas más estables históricamente con las formas de feminidad, esto no debería implicar una tensión. ¿Por qué no podían convivir?

\section{E) Algunas reflexiones}

Como pudo seguirse a lo largo del texto, la inclusión de la práctica de la natación femenina en Argentina hacia las primeras décadas del siglo XX denotó ciertos patrones sociales de comportamiento en el ámbito de la vida privada, a partir de sus pedagogías, de las formas del ocio y las posibilidades de su competencia. En torno a esto la prensa contribuyó con una narrativa escrita y visual fundada en una variedad de temáticas y de tipos de imágenes, influenciada por movimientos transnacionales y nuevas experiencias culturales.

Pudo verse que en las primeras décadas del siglo XX, así como se diversificaron los estereotipos, fueron creciendo las representaciones de aficionadas a las actividades físicas, especialmente entre la segunda y la 
tercera década. La revalorización del deporte en su función restauradora también resultó ser una práctica social integrativa vinculada con nuevos estilos de vida y del ocio modernos.

La mayoría de los mensajes parecen tener como destinatario un público femenino de cierta sensibilidad de grupos medios, para incentivar y regular las características y móviles de las prácticas. Existió un peso moral y una manera de remarcar lo que era o no aceptado según cánones de época. Es decir que se pudo evidenciarse el uso de la prensa o de las imágenes para establecer criterios normados, para fomentar hechos o deportes y a la vez invisibilizar otros. En este sentido, combinar la perspectiva feminista nos dió herramientas para pensar y tener reflexiones críticas sobre determinados discursos, practicar enfoques no encapsulados a miradas totalizadoras, esencialistas, para potenciar y complejizar los mensajes.

Cuando las notas se repetían, construían estereotipos, y esto reforzó imaginarios limitantes, pero a la vez activó transformaciones culturales. Así, por ejemplo, la inclusión cada vez mayor de imágenes femeninas practicando actividades físicas echó luz sobre nuevos referentes. La mención de personajes femeninos destacados fue necesaria para identificar un tipo de mujer occidental moderna, audaz y desafiante que en varios sentidos transgredió las marcas del género y abrió caminos no explorados. No dejan de ser una excepción por el hecho de transgredir límites, es decir, los términos de una construcción diferente del género también subsisten en los márgenes de los discursos hegemónicos.

En el inicio, las deportistas fueron mencionadas como fenómenos extraordinarios. La relación prioritaria era la salud. El entorno de las piletas y los clubes se tiñó de este fenómeno del espectáculo y la pileta se transformó en un espacio de sociabilidad caracterizado por la proximidad de los cuerpos. Las mujeres enfrentaron en estos eventos, los dilemas que planteaba la modestia versus la practicidad en su atuendo. Así se condicionó también la apariencia en el vestir.

En la tercera década del siglo se exaltó el rol de la corporalidad esbelta y movilizada como eje medular, por lo cual la práctica del deporte en general y de la natación en particular fueron altamente estimulados. Un modelo de belleza integral, un cuerpo formado y esbelto que exaltaba la estética que identificaba a la mujer moderna. Los atributos sexuales del cuerpo seguían siendo atractores primarios para la mirada masculina.

Pese a esto, es interesante pensar que propició nuevas relaciones con ellas mismas cuando comenzaron a desmantelarse ciertas ideas sobre el deporte como una actividad restrictiva y masculina.

Mejorar su salud y su estado físico como actos de voluntad y también el encuentro intergenérico, lograr autonomía, camaradería, compartir momentos de diversión y ocio y la pasión por la disciplina competitiva. Son formas de resistencia, el cuerpo como lugar para conectarse con otra estética no esencialista, y producir la corporalidad. Apropiaciones que resignifican la corporalidad, no se dan de forma individual, están dentro de ciertas estructuras, en este caso en el mundo del deporte. Da la sensación que los avances en materia de modernización femenina habrían comenzado a dar sus frutos en la participación del deporte, tal como anunciaban con optimismo las crónicas gráficas.

\section{FUENTES DOCUMENTALES}

¿Sabe usted nadar? (5 de febrero de 1941). Viva Cien Años, p.608.

Anales de la Sociedad Militar. (1916), n 15517.

Breves lecciones de natación. (25 de mayo de 1926). Fray Mocho, s/p.

De Norte América. Notas gráficas del Gran Concurso de Natación celebrado en Brighton. (19 de noviembre de 1921). Caras y Caretas, s/p.

Deportes veraniegos-La lección de natación. (23 de diciembre de 1905). Caras y Caretas, s/p.

El arte de la zambullida. (27 de agosto de 1938). Caras y Caretas, s/p.

En la pileta de natación. (noviembre de 1926). Plus Ultra, s/p.

En las piletas de natación comienza la ofensiva contra el calor de verano. (21 de diciembre de 1935). Carasy Caretas, s/p. 
Enseñanza práctica de la natación. (8 de febrero de 1902). Caras y Caretas, s/p.

Imagen de portada. (6 de enero de 1939).El Gráfico, s/p.

La mujer en el deporte. (9 de mayo de 1936). Caras y Caretas, s/p.

La pileta de natación de la señora Candelaria F. de Duhau. (2 de febrero de 1929). Caras y Caretas, s/p.

Secretos de belleza. (11 de marzo de 1911). Caras y Caretas, s/p.

Torneo Panamericano. (27 de enero de 1939). El Gráfico, s/p.

Una tarde en los clubs sportivos porteños. (13 de enero de 1936). La Nación, s/p.

\section{REFERENCIAS BIBLIOGRÁFICAS}

Anderson, P. (2015). "Mens sana in corpore sano": deportismo, salud y feminidad en Argentina, 1900-1945. En Scharagrodsky. P. (comp.) Miradas médicas sobre la cultura fisica en Argentina 1880-1970. Buenos Aires, Argentina: Prometeo Libros.

Archetti, E. (2001). El potrero, la pista y el ring: Las patrias del deporte argentino. Buenos Aires, Argentina: Fondo de Cultura Económica, FCE.

Arfuch, L. (1996). Una mujer es una mujer. Notas para una semiótica de lo femenino en los medios. Revista Mora, Facultad de Filosofia y Letras, 2, 112- 124.

Berger, J. (2000). Modos de ver. Barcelona, España: Gustavo Gili, SL.

Bontempo, P. (2016). El cuerpo de la mujer moderna. La construcción de la feminidad en las revistas de Editorial Atlántida, 1918-1933. En Scharagrodsky, P. (comp.), Mujeres en movimiento: deporte, cultura fisica y feminidades: Argentina 1870-1980. Buenos Aires, Argentina: Prometeo Libros.

Bourdieu, P. (1991). La distinción. Criterio y bases sociales del gusto. Madrid, España: Taurus.

Bourdieu, P. (1992). How can one be a sports fan? During, S. (Ed.) The cultural studies reader (pp.339-356). Londres, England: Routledge.

Bourdieu, P. (2000). La dominación masculina. Barcelona, España: Anagrama.

Butler, J. (1988). Gender trouble: feminism ans subversión of identity. New York, Estados Unidos: Routledge.

Butler, J. (2007 [1990]). El género en disputa. El feminismo y la subversión de la identidad. Barcelona, España: Paidós.

Chartier, R., Vigarello, G. (1982). Las trayectorias del deporte. Prácticas y espectáculo. Apunts: Medicina de l'esport, $19(76), 289-305$.

Crenshaw, K.(1991). Mapping the margins: Intersectionality, identity politics, and violence against women of color. Stanford Law Review, 43(6), 1.241-1.299.

Crenshaw, K. (1989). Demarginalizing the intersection of race and sex: A black feminist critique of antidiscrimination doctrine, feminist theory and antiracist politics. University of Chicago Legal Forum, 140, 139-167.

Cubillos A. (2014). Reflexiones sobre el proceso de investigación. Una propuesta desde el feminismo decolonial. Athenea Digital, 14(4), 261-285.

Di Liscia, M.S. (2003). Saberes, Terapias y Prácticas médicas en Argentina (1750-1910). Madrid, España: Consejo Superior de Investigaciones Científicas.

Diccionario enciclopédico hispano-americano de literatura, ciencias y artes. (1887-1910). Tomo 13, Barcelona, España: Montaner y Simón

Dominguez, Y. (2019). Revelando estereotipos que no nos representan. TED ex Madrid. Recuperado de https://ww w.ted.com/talks/yolanda_dominguez_revelando_estereotipos_que_no_nos_representan?language $=e s$

Elías N. y Dunning E. (1992). Deporte y ocio en el proceso de la civilización. Madrid, España: Fondo de Cultura Económica.

Featherstones, M, Hepworth, M., Turner, B. (2001). The body. Social process, Cultural Theory. London, England: Sage.

Felitti, K., Queirolo, G (2009). Cuerpos, género y sexualidades a través del tiempo. En Elizalde, S., Felitti, K., Queirolo, $\mathrm{G}$ (coord.) Género y sexualidades en las tramas del saber. Revisiones y propuestas. Buenos Aires: Libros del Zorzal. 
Guttmann, A. (1978). From Ritual to Record: The Nature of Modern Sport. Nueva York, USA: Columbia University Press.

Helfand, J. (2008) First In A Series: Cartophily Design Observer. Ogden Optical Illusion Cards, early 1930s, Design Observer. Recuperado en: https://designobserver.com/feature/first-in-a-series-cartophily/7147

Hill Collins, P. (1990/2000). Black feminist thought. Knowledge, consciousness, and the politics of empowerment. New York, USA: Routledge.

Hooks, B. (1984/2004). "Mujeres negras. Dar forma a la teoría feminista”, en Hooks, B.; Brah, A.; Sandoval, C.; Anzaldúa, G.(Eds) Otras inapropiables. Feminismos desde las fronteras, traducción de Rocío Macho, Hugo Romero, Álvaro Salcedo y María Serranos. Madrid, España: Traficantes de sueños.

Kaczan G. (2013). Salud, belleza, aire libre. Montaje de la apariencia femenina a orillas del mar (circa 1920-1940). Arenal, Revista de Historia de las Mujeres, España, Universidad de Granada, Instituto de la Mujer, 20(1), 129-157.

Lipovetsky, G. (2002). El imperio de lo efimero: la moda y su destino en las sociedades modernas. Barcelona, España: Anagrama.

Love, C. (2008). A social History of Swimming in England, 1800-1918. New York, USA: Routledge.

Monteverde. R. J. Cronologia de la natación argentina: Siglo XIX, Basado en la recopilación de Centro de Documentación Histórica sobre Educación Física y Deportes.

Moraga, C. y Anzaldúa, G. (Eds.) (1981). This Bridge Called My Back: Writings by Radical Women of Color. New York, USA: Persephone Press.

Romero Brest E. (1903). Educación física de la mujer. Buenos Aires, Argentina: Las Ciencias Librería y Casa editora de Nicolás Marana.

Salazar, C., Manzo Lozano E. (2009). “Cuestión de género, cuestión de cuerpo: Deportistas pioneras en Colima”. En Educación Física y Ciencia, 11, 41-49.

Scharagrodsky P. (2002-2003). En la educación física queda mucho género por cortar. Educación Física y Ciencia, 6, 103-127.

Scott, J. W. (1999 [1986]). El género: una categoría útil para el análisis histórico. En M. Navarro y C. Stimpson (comps.), Sexualidad, género y roles sexuales. (pp. 37-75). Buenos Aires, Argentina: FCE.

Soto J, Meloni J, Gaiarin J (2011). La natación argentina hasta los Juegos Olímpicos de Beijing. ISDe Sports Magazine - Revista de entrenamiento, 3(9). Obtenido de http://www.isde.com.ar/ojs/index.php/isdesportsmagazine/art icle/view/48

Tubert S. (Ed). (2003). Del sexo al género: los equívocos de un concepto. Madrid, España: Ediciones Cátedra.

Vigarello, G. (2005). Corregir el cuerpo. Buenos Aires, Argentina: Nueva Visión.

Vigarello, G. (2007). Historia de la belleza. Buenos Aires, Argentina: Nueva Visión.

Wiltse, J. (2007). Contested Waters. A social history of swimming pools in America. North Carolina, USA: University of North Carolina Press.

\section{Notas}

1 Agradecemos los comentarios y sugerencias de los evaluadores anónimos de Educación Física y Ciencia.

2 Para ampliar las referencias puede verse Estudios sobre deporte: por qué vale la pena este libro Alabarces Pablo, en Branz, J.; Garriga Zucal, J.; Moreira, V, comp. (2012). Deporte y ciencias sociales: Claves para pensar las sociedades contemporáneas. La Plata: Edulp, pp. 15-34. En Memoria Académica. Disponible en: http://www.memoria.fahce.unl p.edu.ar/libros/pm.408/pm.408.pdf.

Pueden verse, especialmente, los trabajos individuales y compilados de Pablo Scharagrodsky y los estudios de Eduardo Archetti. Daskal, Rodrigo (2020) Deporte y ciencias sociales, Página 12, Buenos Aires, 25 de junio. https://www.pagi na12.com.ar/274309-deporte-y-ciencias-sociales

3 En el contexto argentino se reconocen trabajos sobre la natación que avanzan sobre algunos ejes principales, aquellos que se vinculan con los desarrollos científicos en biomecánica, que se concentran en las incumbencias de la profesionalización, como en las características competitivas y de rendimiento de la modalidad deportiva, aquellos 
que estudian su incorporación en los sistemas educativos, ya sea discusiones sobre los diseños curriculares, su instrumentación, la modalidad de la formación docente, entre otros aspectos. Entre la bibliografía que se ha consultado para hacer este relevamiento se reconocen especialmente, las actas de las diferentes ediciones del Congreso Argentino y Latinoamericano de Educación Física y Ciencias, Facultad de Humanidades y Ciencias de la Educación, Universidad Nacional de La Plata, Buenos Aires, Argentina.

4 Especialmente sobre las relaciones mujeres-deporte en Argentina se han consultado trabajos de Anderson (2015) y Bontempo (2016).

5 Entre ellas puede consultarse Moraga y Anzaldúa, 1981; Hooks, 1984; Hill Collins, 1990/2000; entre otras.

6 "Las Dificultades para Adquirir el Hábito del Ejercicio" en Caras y Caretas, No 1556 (28 de julio 1928).

7 La referencia está dada en Garbit Frederick J. (1898). Woman's Medical Companion. En Drowning in Culture: Gender, Swimming \& Stereotypes, 2017 in http://www.consumingcultures.net/ Recuperado 25/4/2020.

8 Sobre este aspecto, un hecho que habría marcado la promoción de la práctica en Estados Unidos fue el ahogamiento de cientos de mujeres y niños (http://www.consumingcultures.net/2012/08/24/when-culture-kills-a-history-of-drownin g-in-america/) en un naufragio frente a las costas de Nueva York en 1904, porque no sabían nadar. Se hizo una fuerte y exitosa campaña "Aprender a nadar" a partir de la cual se formaron grupos de natación amateur de género mixto en la mayoría de las principales ciudades de EE. UU. Op. cit.

9 Es una figura que sigue causando curiosidad. Fue buceadora, artista de vodevil, conferenciante, escritora y una estrella de cine mudo, poniendo en evidencia las interconexiones entre las diferentes prácticas culturales que se expandían en las primeras décadas del siglo XX. Publicó libros, artículos, dio conferencias, curso por correspondencia sobre acondicionamiento físico, salud y belleza. Para ampliar puede verse, entre otros, Woollacott, A. (2011). Race and the Modern Exotic: Three 'Australian' Women on Global Display. Australia: Monash University Publishing.

10 En el inicio de siglo XX un grupo de aficionados organizó sus actividades en torno a la pileta Balcarce (1902), una institución inglesa patrocinó numerosos concursos en ese lugar y años más tarde se creó el Club Argentino de Natación, participando en diferentes eventos nacionales e internacionales, convirtiéndose en un lugar visitado por importantes figuras argentinas de la elite. Cuando se construyó la piscina de la Asociación Cristiana de Jóvenes (1911), se aunaron los esfuerzos para promocionar la natación a través de diferentes eventos de enseñanza y competición. En enero de 1921 se fundó la Asociación Argentina de Natación y Waterpolo.

11 Se mencionan números espacios entre ellos el Balneario Municipal, la pileta del Club Atlético Quilmes, el Natatorio del Hindú Club, el Natatorio del Club Obras Sanitarias, Club Deportivo del Comercio, Club Atlético River Plate, Club El Rincón, Gimnasia y Esgrima, la Pileta de Dose y Lariviere, piletas privadas en El Tigre, pileta en el parque Olivera, entre otras.

12 En este período las revistas y el cine difunden por primera vez a gran escala imágenes femeninas ideales. Este ideal fortaleció la similitud entre imágenes del deporte y el cine, de propagandas de cremas con imágenes de competencias Bontempo (2016). El estilo de maquillaje y peinado, las posturas forzadas y provocativas, incluso el tipo de calzado recuerdan los planos fílmicos de Hollywood que vacilaban entre la inocencia y la perdición que, al mismo tiempo, avivaban la mirada de los varones y no dejaban de erigirse como ideal erótico. No es casual que en estos mismos medios gráficos se registrara a las stars en playas extranjeras o sobre un fondo escenográfico de ribera, luciendo trajes de baño de última moda. Ellas ganaban dinero, se divertían practicando deportes y fumando en público, eran admiradas socialmente y parte del éxito estaba dado por el modo en que lucía su fisonomía.(Kaczan, 2012).

13 Las Olimpíadas se vivieron como un evento de trascendencia mundial como un punto alto de competición, generaron gran entusiasmo entre los aficionados y las revistas lanzaron ediciones especiales. Es interesante pensar, cuáles fueron los valores allí promovidos dado que su realización se dió bajo un régimen totalitario como el nazismo que postulaba jerarquías raciales basadas en la eugenesia. 